\title{
Challenges for integrated pest management of Dasineura brassicae in oilseed rape
}

\author{
Johannes Hausmann ${ }^{1}$ (D) \\ Received: 23 April 2021 / Accepted: 9 August 2021 / Published online: 23 August 2021 \\ (c) The Author(s) 2021
}

\begin{abstract}
The use of insecticides in flowering oilseed rape (Brassica napus L.) against pest insects such as the brassica pod midge (Dasineura brassicae W.) often conflicts with the protection of pollinating and beneficial insects. Dasineura brassicae is a major pest insect in European oilseed rape production. However, a comprehensive and sustainable pest control strategy within the framework of integrated pest management (IPM) does not exist, and little research on the insect has been published during the past two decades. This paper reviews the existing knowledge about $D$. brassicae along its life cycle and is intended to form the basis for further research activities on pod-damaging pest insects in oilseed rape. Important knowledge gaps are identified, regarding the significance of natural enemies, diapause induction, and predictions on damage potential, based on initial pest insect population. The short lifespan of the adults is particularly challenging in praxis. The implementation of IPM for D. brassicae is discussed on the basis of the four IPM steps (set an economic threshold, establish pest monitoring, preventive measures, and direct control measures) and remaining hurdles, as well as potential solutions for a better IPM, are identified. For $D$. brassicae, there is no science-based economic threshold and no applicable monitoring methods for farmers, which hinders a field-specific damage forecast and the precise timing of insecticide applications. Research into improved monitoring (e.g. selective attractants, real-time monitoring using remote-sensing technologies) appears to be a promising step towards an integrated pest management of D. brassicae.
\end{abstract}

Keywords Insect pests $\cdot$ Monitoring $\cdot$ Pest control $\cdot$ Economic threshold

\section{Introduction}

Integrated pest management (IPM) is considered to be the standard in modern agriculture (Dara 2019; European Commission 2020). It aims to establish sustainable crop management systems, with effective regulation of pest organisms by natural antagonisms and environmentally friendly measures. There are various approaches how to implement IPM strategies in practice, all covering the following four steps as core elements (Barzman et al. 2015; Ehler 2006; Hokkanen 2015). At first, an economic threshold is set, then a pest

Handling Editor: Severin Hatt.

Johannes Hausmann

johannes.hausmann@julius-kuehn.de

1 Julius Kühn Institute (JKI)-Federal Research Centre for Cultivated Plants, Institute for Plant Protection in Field Crops and Grassland, Messeweg 11-12, 38104 Brunswick, Germany monitoring is established, preventive measures are taken, and only as the last option, chemical control is used.

Oilseed rape, Brassica napus L., (Brassicaceae) (OSR) is one of the most important break crops in cereal-dominated crop rotations in Europe (Lundin 2021; Zheng et al. 2020). Its seeds are processed into versatile oil for human nutrition, industry, and biodiesel, and its by-products are used as animal feed (Friedt and Snowdon 2009). A major challenge in the cultivation of OSR is the control of various pest insects that cause average annual yield losses of $15 \%$ across Europe (Zheng et al. 2020). Substantial efforts have been made to develop IPM strategies in oilseed rape production, and extensive knowledge on pest insects has been published (Alford et al. 2003; Nilsson et al. 2015; Williams 2010a). Nevertheless, there is still no IPM strategy for the brassica pod midge, Dasineura brassicae Winnertz (Diptera: Cecidomyiidae) and there has been little research on this insect during the last two decades. Dasineura brassicae is a major pest insect of OSR and widely spread throughout all important growing areas in Europe and in parts of China 
(Alford et al. 2003; Zheng et al. 2020). During the ripening period of seeds, the larval instars of $D$. brassicae feed on the inner pod walls and secrete enzymes, causing the pods to turn yellowish, swell and deform (Meakin and Roberts 1991). Significant yield losses occur due to a decrease in seed weight by up to $80 \%$ (Williams 2010b) and a premature splitting of the pods, resulting in the loss of seeds (Meakin and Roberts 1991). In traditional OSR growing areas, $D$. brassicae spawns two generations in winter OSR and a third generation develops in spring OSR (Williams et al. 1987a, b). To prevent damage from $D$. brassicae, farmers regularly spray insecticides during the bloom of OSR, which is critical for several reasons. Insecticides are often added to fungicide treatments for Sclerotinia sclerotiorum (Lib.) de Bary and, thus, usually miss the optimal timing aligned with the flight of the first generation of D. brassicae. Additionally, insecticide applications during the bloom of OSR have a particularly high risk to harm non-target organisms, such as pollinators (Karise et al. 2017; Mänd et al. 2010) and many important parasitoids of OSR pest insects (Ulber et al. 2010a). In line with the IPM objectives, pesticides should be applied only after economic thresholds have been exceeded and in a targeted manner. In case of $D$. brassicae, the size of single generations is highly fluctuating and cumulated larval densities of individual years can range from a few

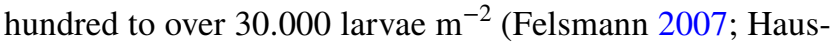
mann et al. 2019). Most studies found the second generation to be the largest (Buhl 1960; Erichsen 1982; Fröhlich 1956a). However, applications against the second generation are not sensible, because OSR branches out during pod set and late applications result in major plant damage along the driving alleys, among other problems. Consequently, the second generation develops undisturbed and can only be controlled indirectly by a reduction of the previous generation. Thus, a thorough understanding of the factors driving $D$. brassiae population dynamics is absolutely necessary for the successful management of this multivoltine pest insect, with only one application against the first generation early in the season. For targeted control, it is important to precisely determine the time point at which a pest insect emerges and immigrates into the crop. Species-specific migration behaviour has a major impact, on which fields, or areas within, will be infested. Knowledge about the maximum reproduction capacity of a single female is important for estimating the maximum possible population increase over several generations at a given pest insect density. These and other aspects are linked to biological traits in the life cycle of $D$. brassicae, which are addressed in the first part of this review. To predict the occurrence of a pest insect and the related damage, the most important factors influencing its population dynamics have to be known. This is analysed in the second part of this review. Together, this information can provide the basis for the development of economic thresholds and decision support systems. The obstacles that currently prevent the implementation of an effective IPM programme against $D$. brassicae and how to overcome those shortcomings, are described in third part of the review.

This review elucidates that the management of $D$. brassicae in agricultural praxis is difficult, because monitoring systems are not yet available and knowledge gaps in the biology allow only vague predictions of pest insect populations and damage, which also prevents the establishment of sustainable thresholds. It is intended to provide a comprehensive overview of the state of knowledge on $D$. brassicae and a basis for further research activities.

\section{Current knowledge on the biology of Dasineura brassicae}

\section{Emergence of the first generation}

Dasineura brassicae hibernates as larva in a cocoon in fields where OSR was grown in previous years (Williams 2010b). After diapause, the larvae pupates inside the cocoons (Buhl and Schütte 1964) and the pupa moves up to the soil surface (Buhl 1960). The emergence of the first generation is mainly driven by soil temperatures (Axelsen 1992b; Hansen 1994; Kirchner 1966). For the development of the cocoons in the soil, 141 day degrees above $8.1^{\circ} \mathrm{C}$ after the first of January are needed (Axelsen 1992b). The first generation of midges emerges when the soil temperature in $5 \mathrm{~cm}$ depth exceeds $15^{\circ} \mathrm{C}$ and air temperature is around $19{ }^{\circ} \mathrm{C}$ (Kirchner 1966), which coincidences with the early flowering stage of OSR in most years (Fröhlich 1956a; Williams et al. 1987a). Pupation itself is not influenced by soil moisture (Erichsen 1982; Hughes 1998; Kirchner 1966). However, soil moisture affects the warming of the soil and the mechanical resistance for the movement of pupae to the soil surface (Blume et al. 2016). Consequently, the emergence of midges within one field can vary due to small-scale differences in soil moisture and soil type and depends also on the depths at which the cocoons were located in the soil. The flight period of the first generation lasts about 3-6 weeks (Williams et al. 1987a). Shifting temperatures can delay emergence, and often there is no constant flight, but several waves of migration.

The emergence of $D$. brassicae occurs mainly in the morning (Buhl 1960). At the emergence site, virgin females show a "calling behavior" and release a sex pheromone (Williams and Martin 1986) that is produced by glandular tissue in the epidermis of an intersegmental membrane in the ovipositor (Isidoro et al. 1992). After mating, the females immediately search for host plants, which is illustrated by the curve of the flight activity at the emergence sites (Murchie et al. 2001). It was observed that the curve is unimodal with a peak for males at 9:00 (searching for virgin females) 
and time shifted at 11:00 for females (mated females search for suitable host plants). There is no flight activity at night time (Murchie et al. 2001) (Fig. 1).

\section{Finding and accepting host plants}

In general, the range of dissemination of $D$. brassicae is rather low. In search of new host plants, the females mainly fly downwind (Sylvén 1970). Just as they deflect the wind, hedges, and other landscape elements can act as barriers or sluices for the dispersal of $D$. brassicae. Distances of up to $500 \mathrm{~m}$ upwind were observed only at low wind speeds of max. $4.5 \mathrm{~m} \mathrm{~s}^{-1}$ (Schütte 1964), which indicates an olfactorymediated upwind anemotaxis. This was confirmed by olfactometer bioassays in which mated females (but no males) were attracted to leaves and pods of OSR (Pettersson 1976) and crushed OSR leaves (Williams and Martin 1986). At a shorter distance, males and females of $D$. brassicae respond positively to the yellow colour of the flowers (Williams and Cook 2010).

Host plants of $D$. brassicae are OSR, close relatives such as turnip rape (Brassica rapa subsp. oleifera), cabbage (Brassica oleracera), and some cruciferous weeds. In general, the survival on Brassica spp. is higher than on other cruciferous plants, which only serve as hosts to a limited extend (Åhman 1988; Speyer 1925). In choice tests between OSR and other crucifers, females did land more frequently on OSR and the number of batches per ovipositing female was higher (Åhman 1988). The initial host plant adaption behaviour is probably elicited by the wax composition of the

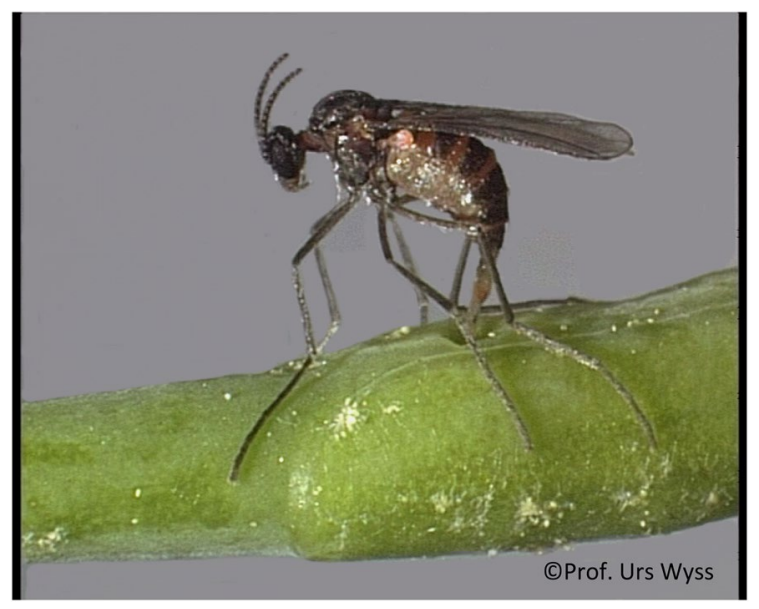

Fig. 1 Female of Dasineura brassicae. The adults of $D$. brassicae are delicate with body length of 0.7-1.5 mm ( $\left.\delta^{\lambda}\right)$ and $0.9-2.2 \mathrm{~mm}($ ( + ), respectively (Kirk 1992). Males have stalked antennae with annular sensory hairs. Distinctive features of the female are the non-stalked antennae and the ovipositor. The three larval instars live gregariously within the pods and grow up to $2 \mathrm{~mm}$. The first larval instar is almost translucent, and older larvae are white coloured with yellow fat bodies cuticula (Åhman 1986). On a potential host plant, females can be observed walking along pods. Tactile and sensory stimuli are perceived by the tarsi and antennae (Coutin 1964). In most cases, females lay their eggs in pods that were previously damaged (Åhman 1987). Potential oviposition sites are externally palpated with the maxillary palps and finally investigated by the insertion of the ovipositor which is equipped with different types of sensory hairs at its tip (Hallberg and Åhman 1987).

\section{Reproduction of Dasineura brassicae}

Virgin females produce up to 140 eggs in their ovaries (Sylvén (1949) cited by Axelsen 1992a); however, the average number of eggs laid per female is estimated to be around 60 (Buhl and Schütte 1971). Adult midges were observed licking on plant sap (Fröhlich 1960), but no feeding behaviour of the adults was observed so far. Whether egg maturation in $D$. brassicae is proovigenic, or whether additional eggs also mature after eclosion, is not yet known. However, fecundity is correlated with the body length of a female (Sylvén (1949), cited by Åhman 1985), which indicates that all eggs mature before eclosion. Environmental stimuli affect oviposition as well. According to Fröhlich (1956a) temperatures above $19^{\circ} \mathrm{C}$ are preferred for oviposition. Additionally, the quality of a host plant influences the egg loads and at a later stage, larval weights which are higher on suitable hosts, compared to low-quality hosts (Åhman 1988). Females lay their eggs in several batches, and there is evidence for monogeny of broods of a single midge (Murchie and Hume 2003). Regarding the overall sex ratio in D. brassicae, several authors described a slight bias towards females (Buhl 1960; Fröhlich 1956a; Murchie and Hume 2003).

The development of the eggs and larvae depends on temperature (Axelsen 1992b; Hughes 1998). Eggs hatch after 3-4 days and the egg-larval stage of the first generation needs $134^{\circ} \mathrm{DD}$ above a developmental threshold of $6.7^{\circ} \mathrm{C}$, which lasts about 3-4 weeks in the field (Axelsen 1992b). At maturity, larvae leave the pods and drop down to the soil where they burrow in 0-5 cm depth (Buhl 1960; Fröhlich 1956a).

According to Buhl (1960) about 5\% of the first-generation larvae, but almost $80 \%$ of the second-generation larvae enter winter diapause. In contrast, Axelsen et al. (1997) found that the proportion of larvae that enter diapause varies within a season and between years and is not constantly increasing in every generation. The authors suggested that the cumulative solar radiation perceived by the growing larvae triggers diapause. Still the specific factors that control diapause induction remain unknown. Additional, not all diapausing larvae pupate in the following year, e.g. Schütte (1979) investigated that $13 \%$ of the overwintering larvae did not emerge in spring following diapause. Diapausing larvae of 
D. brassicae can survive in the soil for up to 5 years (Buhl 1960; Nilsson et al. 2004), but there is a negative correlation between the duration of the cocoon stage in the soil and the average lifespan of adults (Schütte 1979).

\section{Life expectancy of Dasineura brassicae}

In the field, a life expectancy of 1-3 days is assumed for adult $D$. brassicae (Williams 2010b), though conclusive reports on the lifespan of $D$. brassicae are missing. Hughes (1998) demonstrated that the lifespan of D. brassicae is temperature dependent; however, experiments were biased because midges had no access to water and did not survive longer than $48 \mathrm{~h}$ in any of the temperature regimes.

To shed more light on this question, I have conducted an experiment in which larvae of the second generation were collected in the field in 2019 and were held for almost one year in moist sand at $5{ }^{\circ} \mathrm{C}$ in the climate chamber, before they were reared to adult midges. The midges used for this experiment, emerged from the same sample in the morning of the 16th June 2020. Groups of five females were transferred into transparent plastic cups $(500 \mathrm{ml}$, height $16.5 \mathrm{~cm}$ ), which had three openings (each $4 \mathrm{~cm}^{2}$ ), covered with gauze to allow the circulation of air. A water saturated cube $\left(3.5 \mathrm{~cm}^{3}\right)$ of floral foam in each cup supplied moisture to the midges. The foam cubes were resupplied with drops of tap water every $12 \mathrm{~h}$ through the top gauze net. Each six cups (replicates) were placed in climate chambers (RUMED ${ }^{\circledR}, \mathrm{P} 210$ ) at constant temperature levels of $10{ }^{\circ} \mathrm{C}, 15^{\circ} \mathrm{C}, 20^{\circ} \mathrm{C}$, and $25^{\circ} \mathrm{C}$. The experiments started at 12 a.m., and the mortality of the midges was recorded every six hours for three days. Thereafter, assessments were made every $12 \mathrm{~h}$.

Data analysis was performed using $\mathrm{R}$ (version 3.6.1) (R Core Team 2019). A generalized linear model (glm) explaining the number of dead midges per cup by temperature treatments and time was fitted. A binomial error distribution was assumed. The effects of different variables were tested via an analysis of deviance using the "Chitest". For model diagnostics, the residuals were plotted against the predicted values and the explanatory variables and were checked visually. The $\mathrm{LT}_{50}$ values were calculated using the function dose.p from the MASS package (Venables and Ripley 2007). The effect of different temperatures on the mortality of midges over time was also analysed using Kaplan-Meier survival analysis.

As a result, $50 \%$ of female $D$. brassicae were alive for $35 \mathrm{~h}(\mathrm{SE} \pm 1.2)$ at $25^{\circ} \mathrm{C}(\max .66 \mathrm{~h})$ (Fig. 2). At a constant temperature of $10^{\circ} \mathrm{C}$, the $\mathrm{LT}_{50}$ was $224 \mathrm{~h}(\mathrm{SE} \pm 6.8)$ and single females lived up to 17 days. Adult lifespan was significantly dependent on temperature treatments (Kaplan-Meier survival analysis, $p<0.001$ ). This outcome confirmed that under humid conditions, adult lifespan is inversely related to temperature.
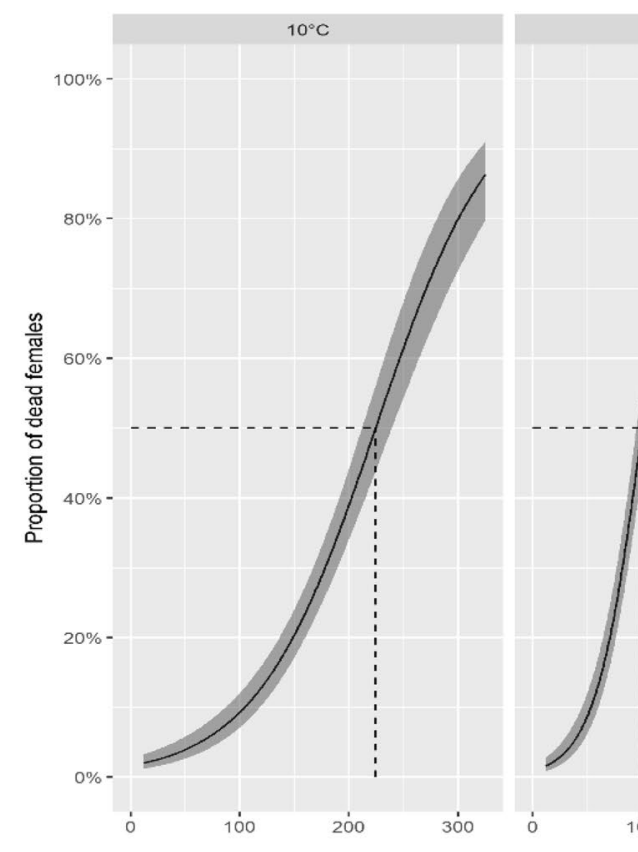

$15^{\circ} \mathrm{C}$

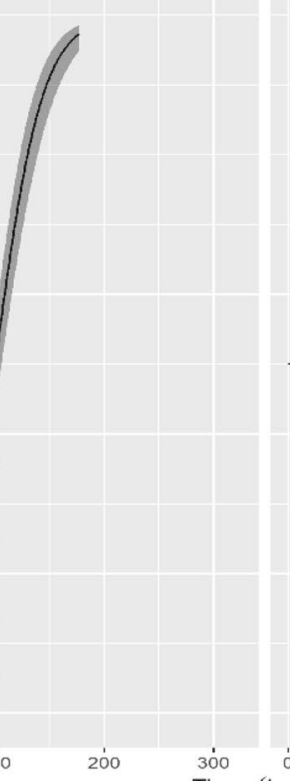

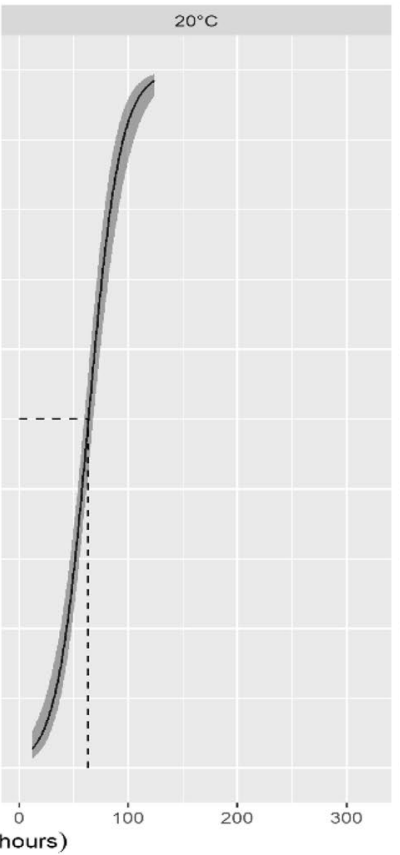

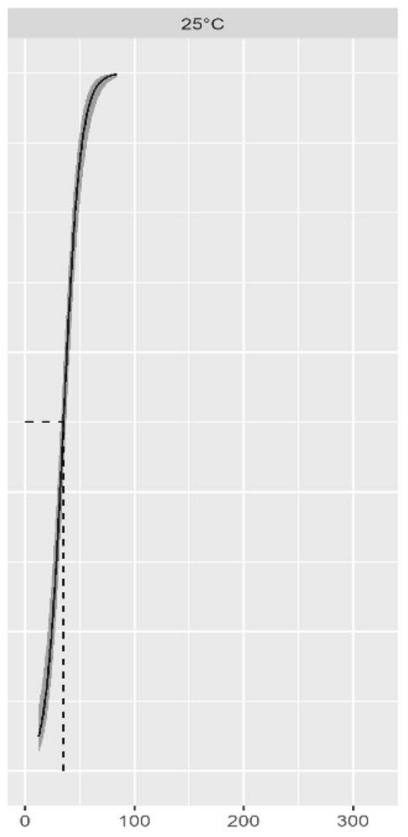

Fig. 2 Calculated mortality with 95\% confidence limits of Dasineura brassicae females over the time (hours). Midges were kept in plastic cups with a moist cube of floral foam at constant temperatures. Dashed lines indicate the time after which $50 \%$ of the midges have died $\left(\mathrm{LT}_{50}\right) . n=30$ 


\section{Drivers of population dynamics}

A distinction can be made between factors that have the potential to promote population dynamics of $D$. brassicae and others that have negative effects (Fig. 3).

Regarding the life cycle, Axelsen (1992c) identified two critical life stages, in which the population of $D$. brassicae suffers larger losses, namely the pre-cocoon stage and the diapause during winter. The author calculated a generation survival of about 2-4\% (Axelsen 1992c). During the precocoon stage, which is the time period between the dropping of larvae from the pods until they spin a cocoon in the soil, losses may occur because of predation by carabids (Warner et al. 2000) and spiders (Felsmann 2007). In addition, dry weather conditions that lead to desiccation are being discussed (Axelsen 1992c). The losses during diapause can be attributed to parasitism (Ferguson et al. 2004; Murchie 1996), pathogens (Hokkanen et al. 2003), and adverse effects of tillage, e.g. ploughing (Axelsen 1992c). There is still a need for research on all of these points.

Weather conditions can affect the population dynamics of D. brassicae in different ways. As described, many physiological processes, like the emergence of the first generation, egg laying, larval and pupal development, and lifespan, are temperature dependent. Warmer temperatures reduce the developmental time of eggs, larvae, and pupae, resulting in a faster generation turnover. Whether diapause is induced by environmental conditions remains to be investigated. On the other hand, it seems likely that quickly changing weather conditions during the flight period of the first and second generation, especially precipitation, may kill adults and prevent successful oviposition. Strong winds may disperse the first-generation adults and partly prevent colonization of suitable crops.

As mentioned earlier, D. brassicae is reliant on damaged pods for oviposition because the ovipositor is not suitable for piercing or drilling of mature pod walls, as demonstrated by morphological studies (Hallberg and Åhman 1987; Stechmann and Schütte 1978). For this reason, the cabbage seedpod weevil, Ceutorhynchus obstrictus Marsham (Coleoptera: Curculionidae), by injuring on the pods through its feeding and oviposition activity, is considered the most important factor for a severe infestation of an OSR crop with $D$. brassicae (Ferguson et al. 1995; Free et al. 1983; Speyer 1921). Strong increases in the seed weevil population lead to a time shifted growth of the D. brassicae population (Schütte 1979). In many cage trials on OSR, no oviposition of $D$. brassicae could be observed without artificial injury of the pods or the addition of C. obstrictus (Ankersmit 1955; Buhl 1957; Doberitz 1973; Fröhlich 1956b; Hughes and Evans 2003). In contrast, several authors described that $D$. brassicae can also independently oviposit in small and young pods up to a length of $40 \mathrm{~mm}$ (Axelsen 1992c; Fröhlich 1956b; Hoßfeld 1963; Mühle 1951; Nietzke 1976). Thus, $C$. obstrictus is probably more important for the development of the second than the first generation. Also, at low pest insect densities, the abundance of $C$. obstrictus is not limiting the population size of D. brassicae (Axelsen 1992a; Fröhlich $1956 b$ ). This can be explained by the larvae of $D$. brassicae
Fig. 3 The life cycle of Dasineura brassicae, modified after Buhl 1960

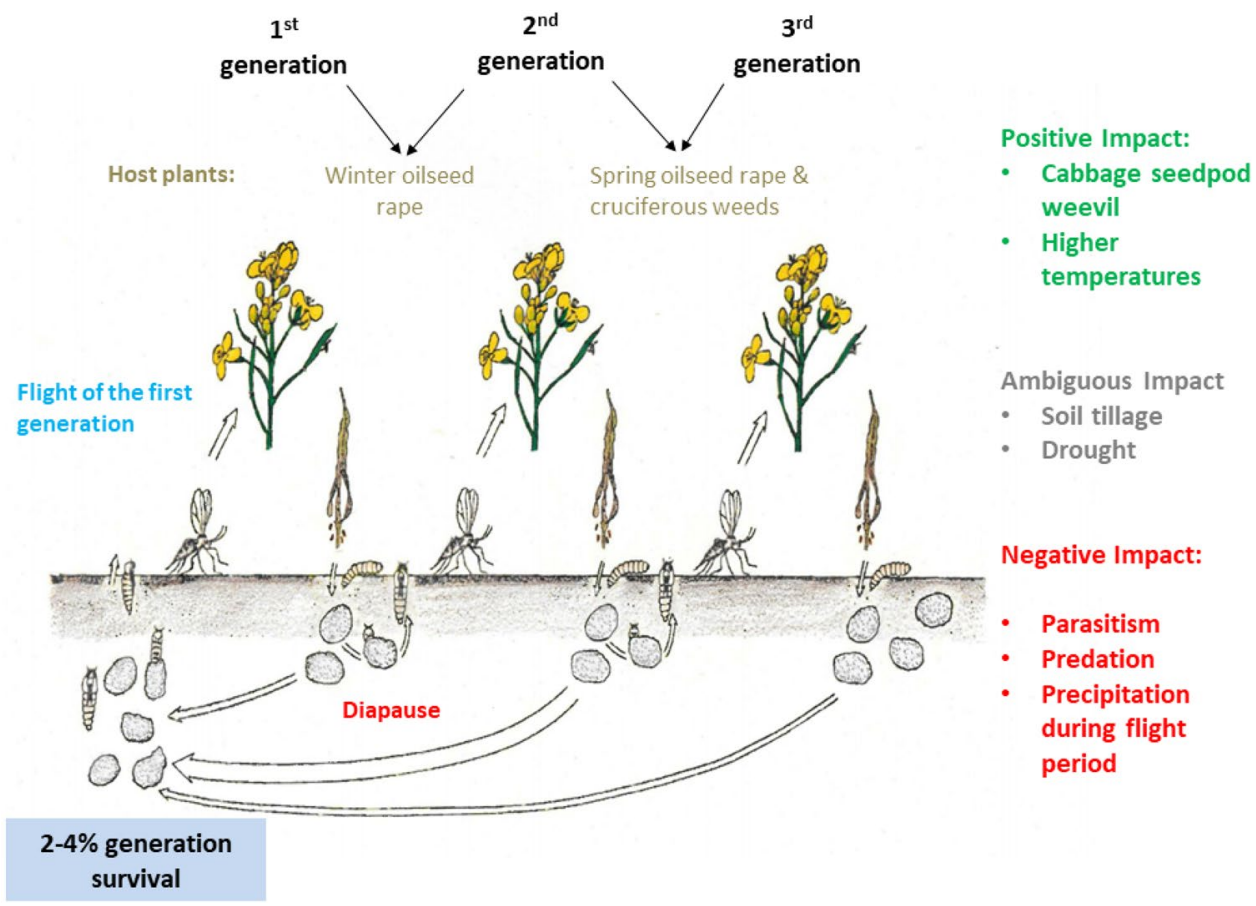


living gregariously and more than one female using a suitable pod for oviposition. For this reason, the average number of larvae within one pod can fluctuate considerably and is dependent on the availability of damaged pods for female midges. In addition, other phytophagous insects, such as lygid bugs [Lygus spp. (Heteroptera: Miridae)] (Hughes and Evans 2003) or abiotic damages such as hail and wind (Winfield 1992), can provide suitable oviposition sites. Concluding, $C$. obstrictus is important for the economic damage potential of $D$. brassicae within one year, but not a mandatory prerequisite.

\section{Challenges for the implementation of integrated pest management}

\section{Defining economic thresholds}

Dasineura brassicae is a typical $r$-strategist, with short generation time and high reproductive capacity. The short lifespan of the adults is particularly challenging for farmers, because the midges start egg laying immediately after their emergence in OSR, leaving little time for control measures. As stated above, it was shown that the abundance of the weevil $C$. obstrictus at full flowering promotes pod damage by D. brassicae later in the season. However, predation, parasitism, and weather conditions (especially temperature) seem to be additional important drivers of the midge's population dynamics. Main losses during the life cycle occur during the winter diapause and the overall generation survival is low. Nevertheless, small numbers of individuals seem to be able to build up a strong population over the season, if conditions are favourable. Hence, the shift from the first to the second generation should be the focal point for the overall reproduction capabilities and population size within one season. Altogether, it is difficult to make a prediction about the population dynamics of two generations, at the time when the decision for or against an active control has to be made. This challenge should be met by an economic threshold, the creation of which is the first step of the IPM approach. Therefore, knowledge about the potential damage of a pest insect and the tolerance of a host plant towards a pest insect is needed, as well as a reliable monitoring system (Ramsden et al. 2017).

The overall damage by $D$. brassicae is usually determined by counting infested pods per plant during the ripening stage of OSR (see EPPO Standard PP 1/220). The proportion of damaged pods can exceed $50 \%$, and high infestation rates with yield losses were reported regularly in the past hundred years (Buhl 1960; Döring and Ulber 2012; Fröhlich 1956b; Kirchner 1966; Nilsson et al. 2015; Schütte 1979; Speyer 1925; Thiem 1970). However, the damage is often concentrated at field margins and the head lands (Ferguson et al. 2004; Thiem 1970; Warner et al. 2000). In addition, the proportion of damaged pods cannot be equated with yield losses, since OSR compensates early pod losses up to $10 \%$ by increasing grain weight (Diepenbrock 2000; Erichsen 1982; Williams and Free 1979), and also compensates early pod losses at the main inflorescence on lateral shoots (Pinet et al. 2015). The plant's ability to compensate, however, is less pronounced for damage caused by the second generation of the midge.

Knowing the important driving factors of an insect's population dynamics and their relation to potential damage, an economic action threshold can be derived. Presently, threshold values for direct control of $D$. brassicae do not exist in most European countries. Most commonly, the economic threshold for $C$. obstrictus, the alleged pioneer of the midge, is lowered from one weevil per plant to one weevil per two plants, if both pest insect species occur together (Heimbach 2017; Ramsden et al. 2017). Older thresholds for $D$. brassicae ranged between $0.25-1$ midges per plant (Heimbach 2017; Lauenstein 1993). Other approaches try to predict the damage potential from the overall population size of $D$. brassicae estimated from the number of $D$. brassicae cocoons that are washed out of soil samples. Buhl and Schütte (1964) recommended to treat OSR fields in a region if the number of cocoons with living larvae in the soil exceeds the threshold of 40 per $100 \mathrm{~cm}^{2}$. A similar method is used in several federal states in northeast Germany. Here, the threshold for insecticide applications in the following year against $C$. obstrictus is lowered if the average number of 25 cocoons per $100 \mathrm{~cm}^{2}$ (assessed after the harvest of OSR) is exceeded (Hahn, M pers. communication). However, it should be stated that a scientifically based and peer-reviewed economic threshold does not exist.

\section{Pest monitoring}

The establishment of an economic threshold requires monitoring of the pest insect and represents the second stage in the implementation of an IPM strategy. In case of $D$. brassicae, the monitoring is challenging for several reasons, not least because of the insect's small size (Fig. 1). Adults of D. brassicae can be reliably differentiated from other gall midge species by their specific wing veining (Fig. 4), but this feature is difficult to identify with the naked eye. Consequently, monitoring of $D$. brassicae midges by farmers did never catch on in praxis.

The emergence and flight of the first generation can be monitored by using photoeclectors that are placed at the OSR fields of the previous year (Waede 1960). In addition, there are commercial prediction models that indicate which days are suitable for the first generation of $D$. brassicae to emerge and that also calculate what percentage of the flight period has passed (Johnen et al. 


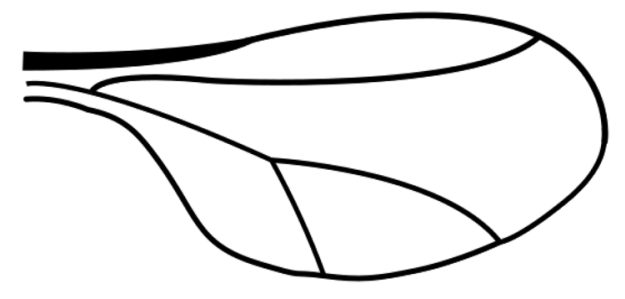

Fig. 4 The veining of Dasineura brassicae, modified after Kirk 1992. Wings have three veins reaching the wing margin. Typically, the long vein from the base ends just before the tip of the wing

2010). Based on regional meteorological data, these prediction models can help farmers to determine the critical time when immigration of $D$. brassicae in their region is probable. Field-specific forecasts are not possible though, since the migration of females to the new crop is affected by factors like wind and the distance from the previous year's OSR fields. Information on which specific fields or parts of a field are colonized is crucial for the implementation of IPM. Yellow water traps are potentially suitable for this purpose, although they create the risk of misidentification, as several similar gall midge species can be found in the OSR fields. For this reason, attempts were made to selectively catch $D$. brassicae using baited traps. The addition of an extract of OSR seeds with a high content of glucosinolates to water traps increased the capture efficiency at the emergence sites (Erichsen and Daebeler 1987). Traps baited with allyl isothiocyanate caught more male and female $D$. brassicae than traps baited with 2-phenylethyl isothiocyanate or unbaited traps (Murchie et al. 1997). However, mostly males were caught in both studies. Traps baited with the sex pheromone of virgin females (Williams and Martin 1986) also selectively caught $D$. brassicae but also predominately males (Williams 1990). Since males usually remain at the emergence sites after mating, their catch is not suitable to predict the colonization of the OSR fields by females. The development of a trap attracting specifically female midges would be a great step forward in the monitoring of $D$. brassicae.

In recent years, agriculture has experienced a trend towards the use of new, innovative technologies. Artificial intelligence and camera traps enable the development of real-time monitoring systems. For example, lidar technology allows insects to be identified in situ by their wing beat, colour, and the proportions of wing width to body size. Technology offers promising possibilities for the monitoring of flying insects (Brydegaard and Svanberg 2018), and first tests with pest insects in OSR have been carried out (Kirkeby et al. 2021).

\section{Preventive measures}

In IPM, preventive measures that reduce pest insect densities are preferable to direct control measures. Such indirect and preventive measures can include cultural measures, crop rotation, resistant cultivars, landscape management, and the enhancement of natural enemies (Hokkanen 2015).

Dasineura brassicae can use spring sown OSR to develop a strong third generation (Axelsen 1992c). For this reason, the growing of winter and spring sown OSR in the same region has been considered a key factor for the development of large $D$. brassicae populations and heavy infestations for a long time (Doberitz 1973; Speyer 1921). To what extent a third generation is limited by the lack of suitable host plants or by the induction of diapause of second-generation larvae, needs to be further investigated. The control of cruciferous weeds, especially on non-crop habitats, was recommended by Speyer (1921). However, it was shown that $D$. brassicae survives only in small numbers on such weeds, which limits the potential of this measure (Åhman 1988). As the dispersal capabilities of $D$. brassicae are limited, the cultivation area of OSR at landscape scale affects the damage potential of the midge as well. The risk of infestation is reduced to less than half, if a distance of more than $3 \mathrm{~km}$ of this year's OSR is maintained from the previous year's cropland (Erichsen 1982). To interfere with the build-up of high pest populations, the interruption of OSR cultivation at a landscape scale is suggested as a possibility (Zheng et al. 2020). This was successfully demonstrated for $C$. obstrictus and D. brassicae in a one-season trial in northern Germany (Schütte 1979).

Soil tillage affects the vertical distribution of cocoons in the soil (Buhl 1960; Froese 1992). Ploughing did neither reduce the number of $D$. brassicae cocoons in the soil (Nielsen et al. 1994) nor the total emergence of adults in spring (Axelsen 1995), though the temporal distribution of the emergence was expanded. Still, some authors assume that ploughing is an important mortality factor for $D$. brassicae (Axelsen 1992c; Ferguson et al. 2004; Williams 2010b).

Dasineura brassicae can discriminate between low- and good-quality hosts (Åhman 1988). The differences in alighting frequency between different Brassica spp. indicate the possibility of antixenosis (Åhman 1988). The lower rates of survival and larval weights on low-quality hosts are probably related to lower nutritional values or substances that are harmful for D. brassicae (Åhman 1985), which could be seen as a kind of antibiosis. In summary, these are different starting points for breeding resistant cultivars. However, successful resistance breeding against $D$. brassicae is not foreseeable yet based on the limited knowledge of variability in resistance of OSR and related species for this pest.

Natural enemies contribute to the control of $D$. brassicae populations by predation and parasitisation. At least 31 
parasitoid species parasitize eggs and larval stages of $D$. brassicae (Ulber et al. 2010b). The key parasitoid species are Platygaster subuliformis (Hymenoptera: Platygastridae) and Omphale clypealis (Hymenoptera: Eulophidae), both widely distributed in Central and Northern Europe (Ulber et al. 2010b). However, the multivoltine life history of the host and its parasitoids complicate investigations and extensive studies on parasitism in D. brassicae are scarce. Existing studies indicate substantial variability in parasitism rates (Murchie 1996). In general, parasitism rates post-diapause seem to be higher and can exceed 50\% (Ferguson et al. 2004; Murchie 1996). Predation of larvae might also affect D. brassicae populations. Larvae are especially vulnerable to predation by spiders or ground dwelling predators, when they drop down from the pods to pupate into the soil. Altogether, 11 carabid species fed on pod midge larvae in laboratory studies; however in choice tests, species differed in their preference for $D$. brassicae and in the amount of consumed larvae (Williams et al. 2010). Only Amara similata (Coleoptera: Carabidae) was proven to feed on larvae in field studies (Schlein and Büchs 2006). Spiders may prey on larvae and emerging midges of the first generation. Studies of Felsmann (2007) revealed a temporal coincidence between web densities of linyphiid spiders and both, the dropping of larvae, and the emergence of new generation midges in OSR.

In conclusion, preventive measures can contribute to a reduction of $D$. brassicae infestation to a limited extent. In particular, the potential of natural antagonists, such as predators and parasitoids, should be further explored and promoted through adherence to good agricultural practice (i.e. IPM, use of economic thresholds). The distance to OSR fields of the previous year, and the avoidance of winter and spring sown oilseed rape in the crop rotation, are effective measures to reduce pest pressure.

\section{Control measures}

The brassica pod midge has been a subject of research since 1850 (Winnertz 1853) and different control options have been under discussion so far. Early on, the control of $D$. brassicae was rather indirect, while direct measures aimed for control of the cabbage seedpod weevil C. obstrictus (Speyer 1921). In general, insecticide spray treatments of field margins and headlands are considered adequate for moderate pest insect pressure (Ferguson et al. 2004; Thiem 1970). Today, control of the cabbage seedpod weevil and the brassica pod midge pest insect complex relies mainly on the use of synthetic chemical insecticides. All direct measures target $C$. obstrictus and the first generation of $D$. brassicae. Insecticides with non-systemic properties have to be applied before the main flight, to hit the midges before they start laying eggs. Since OSR is rapidly growing during the flowering period and temperatures can be quite warm, the residual activity of the insecticides will often decline rapidly in the field. Hence, it is a challenge to protect the crop with a single insecticide application, which requires a precise timing of the application. Therefore, reliable and precise monitoring data would be a prerequisite.

Until now, $D$. brassicae is sensitive to insecticides and there is no evidence of insecticide resistance. However, in Germany, increasing pyrethroid resistance in populations of $C$. obstrictus can be observed (Brandes and Heimbach 2019).

Insecticide applications below the flowering canopy of the crop with dropleg technique can reduce side effects on pollinators but tend to have reduced efficacy against $D$. brassicae (Hausmann et al. 2019). Regarding alternative control measures, only few studies have investigated botanicals such as extracts from neem tree (Azadirachta indica) (Pavela et al. 2009) or the application of nitrophenoles (Kazda et al. 2015), which have shown some efficacy in field trials.

\section{Conclusions}

This literature review shows that so far IPM of $D$. brassicae in OSR is rather a collection of promising ideas than state of the art. Most preventive control measures are limited in terms of their efficiencies. Resistance breeding or a largescale interruption of OSR cultivation in individual years is difficult to establish in the short term and more knowledge about the effectiveness of all these measures is needed. De facto, direct control with insecticides remains the most effective control measure, and it is, therefore, essential that it is practiced within the framework of IPM. So far, the most practicable option to predict $D$. brassicae damage appears to be monitoring of $C$. obstrictus, which provides access to pods and so for a mass propagation. However, a clear relation between the two species only exists at high pest insect densities. At present, insecticide sprays in flowering OSR are often retrospectively motivated and tend to have the character of an insurance spray rather than being targeted and economically justified from an integrated pest management perspective. To improve this, the development of an economic threshold for $D$. brassicae is a necessary requirement. So far, it is poorly understood what the number of individuals constitutes the critical threshold for a potential mass propagation within the season. Therefore, the mortality rate of the first generation of $D$. brassicae and other factors favouring the development of a large second generation need to be studied in detail. To be reliable, prediction models of potential crop damages should further include temperature as a variable, as this affects many aspects of population development. However, the absence of long-term weather forecast has a limiting effect. Furthermore, there is great need for an improved method that allows easy monitoring 
of $D$. brassicae. Currently, the identification of midges in the field is not practicable and it is therefore impossible to determine which fields or specific areas within a given field are infested and are likely to suffer crop damage. Promising avenues of research are the development of selective attractants and real-time monitoring of insects, using remote-sensing technology.

Acknowledgements I would like to thank Meike Brandes, Michael Rostás, Jan Schinkel, and Bernd Ulber, who contributed to the work through many discussions and helpful suggestions. My thanks also go to Urs Wyss, who kindly provided a picture of Dasineura brassicae.

Funding Open Access funding enabled and organized by Projekt DEAL. No funding was received for preparing this study.

\section{Declarations}

Conflict of interest There is no conflicts of interest.

Open Access This article is licensed under a Creative Commons Attribution 4.0 International License, which permits use, sharing, adaptation, distribution and reproduction in any medium or format, as long as you give appropriate credit to the original author(s) and the source, provide a link to the Creative Commons licence, and indicate if changes were made. The images or other third party material in this article are included in the article's Creative Commons licence, unless indicated otherwise in a credit line to the material. If material is not included in the article's Creative Commons licence and your intended use is not permitted by statutory regulation or exceeds the permitted use, you will need to obtain permission directly from the copyright holder. To view a copy of this licence, visit http://creativecommons.org/licenses/by/4.0/.

\section{References}

Åhman I (1985) Larval feeding period and growth of Dasineura brassicae (Diptera) on Brassica host plants. Oikos 44:191-194. https:// doi.org/10.2307/3544061

Åhman I (1986) Oviposition in Dasineura brassicae Winn. (Dipt.: Cecidomyiidae): Adaptive, mechanistic, and applied aspects. Växtskyddsrapporter. Avhandlingar, vol 9. Sveriges Lantbruksuniversitet, Uppsala

Åhman I (1987) Oviposition site characteristics of Dasineura brassicae Winn. (Dipt., Cecidomyiidae). J Appl Entomol 104:85-91. https:// doi.org/10.1111/j.1439-0418.1987.tb00501.x

Åhman I (1988) Wild and cultivated crucifers as hosts for Dasineura brassicae Winn. (Dipt., Cecidomyiidae). J Appl Entomol 105:420-424. https://doi.org/10.1111/j.1439-0418.1988.tb002 $05 . \mathrm{x}$

Alford DV, Nilsson C, Ulber B (2003) Insect pests of oilseed rape crops. In: Alford DV (ed) Biocontrol of oilseed rape pests. Blackwell Science, Oxford, pp 9-42

Ankersmit GW (1955) On the relation between the infestation by the cabbage seed pod midge, Dasyneura brassicae Winn. and the seed pod weevil Ceuthorrhynchus Assimilis PAYK. Tijdschrift over Plantenziekten 61:93-97

Axelsen JA (1992) Analysis of the populations dynamics of the pod gall midge (Dasyneura brassicae Winn.) in winter rape and spring rape by computer simulation. Ecol Model 69:43-55. https://doi. org/10.1016/0304-3800(93)90047-V
Axelsen JA (1992) The developmental time of the pod gall midge Dasyneura brassicae Winn. (Dipt., Cecidomyiidae). J Appl Entomol 114:263-267. https://doi.org/10.1111/j.1439-0418.1992.tb011 25. $\mathrm{x}$

Axelsen JA (1992) The population dynamics and mortalities of the pod gall midge (Dasyneura brassicae Winn.) (Dipt., Cecidomyiidae) in winter rape and spring rape (Brassica napus L.) in Denmark. J Appl Entomol 114:463-471. https://doi.org/10.1111/j.1439-0418. 1992.tb01152.x

Axelsen JA (1995) The winter mortality and emergence time of Dasineura brassicae in Denmark. IOBC-WPRS Bul 18:81-87

Axelsen JA, Fink R, Kjaer C (1997) Global solar radiation as the factor controlling induction of diapause in the pod midge (Dasyneura brassicae Winn.). Oecologia 111:178-182. https://doi.org/10. 1007/s004420050223

Barzman M, Bàrberi P, Birch ANE, Boonekamp P, Dachbrodt-Saaydeh S, Graf B, Hommel B, Jensen JE, Kiss J, Kudsk P, Lamichhane JR, Messéan A, Moonen A-C, Ratnadass A, Ricci P, Sarah J-L, Sattin M (2015) Eight principles of integrated pest management. Agron Sustain Dev 35:1199-1215. https://doi.org/10.1007/ s13593-015-0327-9

Blume H-P, Brümmer GW, Fleige H, Horn R, Kandeler E, KögelKnabner I, Kretzschmar R, Stahr K, Wilke B-M (2016) Physical properties and processes. In: Blume H-P et al (eds) Scheffer/ Schachtschabel soil science. Springer, Berlin, pp 175-283

Brandes M, Heimbach U (2019) Pyrethroid resistance of insect pests of oilseed rape in Germany. In: Union zur Förderung von Oel und Proteinpflanzen (ed) IRC 2019 - 15th International Rapeseed Congress : Flowering for the Future : Berlin, Germany, 16.-19.06.2019

Brydegaard M, Svanberg S (2018) Photonic monitoring of atmospheric and aquatic fauna. Laser Photonics Rev 12:1800135. https://doi. org/10.1002/lpor.201800135

Buhl C (1957) Beitrag zur Frage der biologischen Abhängigkeit der Kohlschotenmücke (Dasyneura brassicae Winn.) vom Kohlschotenrüßler (Ceuthorrhynchus assimilis Payk.). Z Pflanzenkrankheiten (pflanzenpathologie) Und Pflanzenschutz 64:562-568

Buhl C (1960) Beobachtungen über das vermehrte Schadauftreten der Kohlschotenmücke (Dasyneura brassicae Winn.) an Raps und Rübsen in Schleswig-Holstein. Nachr Dtsch Pflanzenschutzd $12: 1-6$

Buhl C, Schütte F (1964) Zur Prognose der Kohlschotenmücke (Dasineura brassicae Winn.). Nachr Dtsch Pflanzenschutzd 16:20-23

Buhl C, Schütte F (1971) Prognose wichtiger Pflanzenschädlinge in der Landwirtschaft. Paul Parey, Hamburg, Berlin

Coutin R (1964) Le comportement de ponte chez plusieurs Cécidomyies en relation avec l'état de développement chez la plante-hote des organes recherchés pour l'oviposition. Revue de Zoologie Agricole et Appliquée 63:45-55

Dara SK (2019) The new integrated pest management paradigm for the modern age. J Integr Pest Manag 10:1-9. https://doi.org/10. 1093/jipm/pmz010

Diepenbrock W (2000) Yield analysis of winter oilseed rape (Brassica napus L.): a review. Field Crop Res 67:35-49

Doberitz G (1973) Untersuchungen über die biologische Abhängigkeit der Kohlschotenmücke (Dasineura brassicae Winn.) vom Kohlschotenrüßler (Ceutorhynchus assimilis Payk.) und Vorschläge zur Verbesserung ihrer Bekämpfung. Nachr Bl Pflanzenschutzdienst DDR 27:145-149

Döring A, Ulber B (2012) Ein perfektes Befallsjahr. DLG-Mitt. 5:52-55

Ehler LE (2006) Integrated pest management (IPM): definition, historical development and implementation, and the other IPM. Pest Manag Sci 62:787-789. https://doi.org/10.1002/ps.1247 
Erichsen E (1982) Untersuchungen zum Auftreten der Kohlschotenmücke (Dasineura [Dasyneura] brassicae Winn.) und Möglichkeiten der Überwachung und Bekämpfung [Investigations on the abundance of $D$. brassicae and opportunities for monitoring and control]. Dissertation, Universität Rostock

Erichsen E, Daebeler F (1987) Zur Überwachung der Kohlschotenmücke (Dasyneura brassicae Winn.) im Winterraps. Nachrichtenblatt für den Pflanzenschutz in der DDR 41:33-34

European Commission (2020) A farm to fork strategy for a fair, healthy and environmentally-friendly food system: COM (2020) 381 final. https://eur-lex.europa.eu/legal-content/EN/TXT/?uri=CELEX\% 3A52020DC0381. Accessed 7 June 2021

Felsmann D (2007) The spatio-temporal dynamics of epigaeic predators and insect pests in different oilseed rape management systems. Dissertation, Technische Universität Braunschweig

Ferguson AW, Kenward MG, Williams IH, Clark SJ, Kelm M, Dudzic A (1995) Interactions between the cabbage seed weevil (Ceutorhynchus assimilis Payk.) and the brassica pod midge (Dasineura brassicae Winn.) infesting oilseed rape pods. In: Proceedings 9th International Rapeseed Congress, 1995, 1-2. The Dorset Press, Dorchester, pp 679-681

Ferguson AW, Campbell JM, Warner DJ, Watts NP, Schmidt JE, Williams IH (2004) Phenology and spatial distributions of Dasineura brassicae and its parasitoids in a crop of winter oilseed rape: implications for integrated pest management. IOBC/ WPRS Bull 27(10):243-251

Free JB, Ferguson AW, Winfield S (1983) Effect of various levels of infestation by the seed weevil (Ceutorhynchus assimilis Payk.) on the seed yield of oilseed rape (Brassica napus L.). J Agric Sci 101:589-596. https://doi.org/10.1017/S0021859600038624

Friedt W, Snowdon R (2009) Oilseed rape. Oil crops. Springer, New York, pp 91-126

Froese A (1992) Vergleichende Untersuchungen zur Biologie und Ökologie der Dipteren auf integriert und konventionell bewirtschafteten Feldern. Dissertation, Gießen

Fröhlich G (1956) Zur Biologie und Bekämpfung der KohlschotenGallmücke (Dasyneura brassicae Winn) [Biology and control of brassica pod midge (Dasyneura brassicae Winn)]. Nachr B1 Pflanzenschutzdienst DDR 10:123-128

Fröhlich G (1956) Zur Frage der biologischen Abhängigkeit der Kohlschoten-Gallmücke (Dasyneura brassicae Winn.) vom Kohlschotenrüßler (Ceuthorrhynchus assimilis Payk.). Beiträge Zur Entomologie 6:100-110

Fröhlich G (1960) Gallmücken-Schädlinge unserer Kulturpflanzen. A. Ziemsen Verlag, Wittenberg Lutherstadt

Hallberg E, Åhman I (1987) Sensillar types of the ovipositor of Dasineura brassicae: structure and relation to oviposition behaviour. Physiol Entomol 12:51-58

Hansen LM (1994) Brassica pod midge in winter oilseed rape-strategy for control. Dan Inst Plant Soil Sci 7:167-171

Hausmann J, Brandes M, Heimbach U (2019) Effects of dropleg application technique during flowering of oilseed rape on insect pests. Crop Prot 126:104917. https://doi.org/10.1016/j.cropro. 2019.104917

Heimbach U (2017) Summary of findings from a participant country questionnaire on pest insects in oilseed rape. https://www.eppo. int/media/uploaded_images/MEETINGS/Meetings_2017/ipm/ 05-Heimbach.pdf. Accessed 24 September 2020

Hokkanen HMT (2015) Integrated pest management at the crossroads: science, politics, or business (as usual)? Arthropod Plant Interact 9:543-545. https://doi.org/10.1007/s11829-015-9403-y

Hokkanen HMT, Menzler-Hokkanen I, Butt TM (2003) Pathogens of oilseed rape pests. In: Alford DV (ed) Biocontrol of oilseed rape pests. Blackwell Science, Oxford, pp 299-322
Hoßfeld R (1963) Synökologischer Vergleich der Fauna von Winterund Sommerrapsfeldern. J Appl Entomol 52:209-254. https:// doi.org/10.1111/j.1439-0418.1963.tb02035.x

Hughes J (1998) Investigation of the potential range and colonisation ability of selected insect pests of oilseed rape. Dissertation, University of Edinburgh

Hughes JM, Evans KA (2003) Lygid bug damage as a pod access mechanism for Dasineura brassicae (Dipt., Cecidomyiidae) oviposition. J Appl Entomol 127:116-118. https://doi.org/10. 1046/j.1439-0418.2003.00658.x

Isidoro N, Williams IH, Solinas M, Martin A (1992) Mating behaviour and identification of the female sex pheromone gland in the brassica pod midge (Dasineura brassicae Winn.: Cecidomyiidae, Diptera). Boll Ist Entomol "Guido Grandi" Univ Studi Bologna 47:27-48

Johnen A, Williams IH, Nilsson C, Klukowski Z, Luik A, Ulber B (2010) The proPlant decision support system: phenological models for the major pests of oilseed rape and their key parasitoids in Europe. In: Williams IH (ed) Biocontrol-based integrated management of oilseed rape pests, vol 5. Springer, Dordrecht, pp 381-403

Karise R, Raimets R, Bartkevics V, Pugajeva I, Pihlik P, Keres I, Williams IH, Viinalass H, Mänd M (2017) Are pesticide residues in honey related to oilseed rape treatments? Chemosphere 188:389396. https://doi.org/10.1016/j.chemosphere.2017.09.013

Kazda J, Herda G, Spitzer T, Řičařová V, Przybysz A, Gawrońska H (2015) Effect of nitrophenolates on pod damage caused by the brassica pod midge on the photosynthetic apparatus and yield of winter oilseed rape. Anzeiger für Schädlingskunde 88:235-247. https://doi.org/10.1007/s10340-014-0603-5

Kirchner H-A (1966) Möglichkeiten zur kurzfristigen Voraussage des Auftretensder Kohlschotenmücke Perrisia (Dasyneura) brassicae Winn.) und Beziehungen des Mückenschlupfes zu Witterungsfaktoren. Wiss Z Univ Rostock 15:275-282

Kirk W (1992) Insects on cabbages and oilseed rape. Naturalists' handbooks, vol 18. Richmond Publishing, Slough

Kirkeby C, Rydhmer K, Cook SM, Strand A, Torrance MT, Swain JL, Prangsma J, Johnen A, Jensen M, Brydegaard M, Græsbøll K (2021) Advances in automatic identification of flying insects using optical sensors and machine learning. Sci Rep 11:1555

Lauenstein G (1993) Schwellenwerte für die Bekämpfung von Rapsschädlingen. [Economic thresholds for the control of insect pests in oilseed rape]. Raps 11:27-31

Lundin O (2021) Consequences of the neonicotinoid seed treatment ban on oilseed rape production - what can be learnt from the Swedish experience? Pest Manag Sci. https://doi.org/10.1002/ ps.6361

Mänd M, Williams IH, Viik E, Karise R (2010) Oilseed rape, bees and integrated pest management. In: Williams IH (ed) Biocontrolbased integrated management of oilseed rape pests. Springer, Dordrecht, pp 357-379

Meakin PJ, Roberts JA (1991) Anatomical and biochemical changes associated with the induction of oilseed rape (Brassica napus) pod dehiscence by Dasineura brassicae (Winn.). Ann Bot 67:193197. https://doi.org/10.1093/oxfordjournals.aob.a088122

Mühle E (1951) Zur Frage der Abhängigkeit des Befalls der Cruciferen-Schoten durch die Kohlschotenmücke (Dasyneura brassicae Winn.) von dem Auftreten des Kohlschotenrüsslers (Ceutorrhynchus assimilis Payk.). Nachr Dtsch Pflanzenschutzd 5:173-176

Murchie AK (1996) Parasitoids of cabbage seed weevil and brassica pod midge in oilseed rape. Dissertation, University of Keele

Murchie AK, Hume KD (2003) Evidence for monogeny in the brassica pod midge Dasineura brassicae. Entomol Exp Appl 107:237-241. https://doi.org/10.1046/j.1570-7458.2003.00054.x

Murchie AK, Smart LE, Williams IH (1997) Responses of Dasineura brassicae and its parasitoids Platygaster subuliformis and 
Omphale clypealis to field traps baited with organic isothiocyanates. J Chem Ecol 23:917-926. https://doi.org/10.1023/B: JOEC.0000006380.59526.bd

Murchie AK, Burn DJ, Kirk W, Williams IH (2001) A novel mechanism for time-sorting insect catches and its use to derive the diel flight periodicity of brassica pod midge Dasineura brassicae (Diptera:Cecidomyiidae). Bull Entomol Res 91:199-203

Nielsen BO, Brunberg Nielsen L, Axelsen JA, Elmegaard N (1994) Winter abundance of soil diptera larvae in arable soil. Pedobiologia 38:208-221

Nietzke G (1976) Zum Auftreten der Kohlschotenmücke (Dasineura brassicae Winn.) im Nordharz-Vorraum. Nachr Dtsch Pflanzenschutzd 28:136-140

Nilsson C, Vimarlund L, Gustafsson G (2004) Long term survival of brassica pod midge (Dasineura brassicae) populations. IOBC/ WPRS Bull 27:297-302

Nilsson C, Büchs W, Klukowski Z, Luik A, Ulber B, Williams IH (2015) Integrated crop and pest management of winter oilseed rape (Brassica napus L.). Zemdirbyste-Agriculture 102:325-334. https://doi.org/10.13080/z-a.2015.102.042

Pavela R, Kazda J, Herda G (2009) Effectiveness of neem (Azadirachta indica) insecticides against brassica pod midge (Dasineura brassicae Winn.). Anzeiger Für Schädlingskunde 82:235-240. https:// doi.org/10.1007/s10340-009-0244-2

Pettersson J (1976) Ethology of Dasyneura Brassicae Winn. (Dipt., Cecidomyidae). I. Laboratory studies of olfactory reactions to the host-plant. Symp Biol Hung 16:203-208. https://doi.org/10.1007/ 978-1-4613-4274-8 32

Pinet A, Mathieu A, Jullien A (2015) Floral bud damage compensation by branching and biomass allocation in genotypes of Brassica napus with different architecture and branching potential. Front Plant Sci 6:70. https://doi.org/10.3389/fpls.2015.00070

R Core Team (2019) R: a language and environment for statistical computing, Vienna, Austria. https://www.R-project.org. Accessed 7 June 2021

Ramsden MW, Kendall SL, Ellis SA, Berry PM (2017) A review of economic thresholds for invertebrate pests in UK arable crops. Crop Prot 96:30-43. https://doi.org/10.1016/j.cropro.2017.01.009

Schlein O, Büchs W (2006) The ground beetle Amara similata as a predator of pest larvae in oilseed rape fields; ignored but influential in biological control? In: Georg-August-Universität Göttingen (ed) CD-Rom Proceedings International Symposium Integrated Pest Management in Oilseed Rape, 3-5 April 2006, Göttingen, Germany

Schütte F (1964) Beobachtungen über den Flug der Kohlschotenmücke (Dasyneura brassicae Winn. -Dipt., Cecidomyiidae). J Appl Entomol 55:365-376. https://doi.org/10.1111/j.1439-0418.1964.tb029 93. $\mathrm{x}$

Schütte F (1979) Integrierte Bekämpfung von Rapsschädlingen durch Vermeidung des Zusammentreffens mit ihren Wirtspflanzen. Monographien zur angewandten Entomologie, vol 22. Paul Parey, Hamburg, Berlin

Speyer W (1921) Beiträge zur Biologie der Kohlschotenmücke (Dasyneura brassicae Winn.) [Contributions to the biology of brassica pod midge (Dasyneura brassicae Winn.)]. Mitteilungen Aus Der Biologischen Reichsanstalt Für Land- Und Forstwirtschaft. 21:208-217

Speyer W (1925) Kohlschotenrüßler (Ceutorrhynchus assimilis Payk), Kohlschotenmücke (Dasyneura brassicae Winn) und ihre Parasiten. In: Arbeiten aus der Biologischen Reichsanstalt für Landund Forstwirtschaft, vol 12. Paul Parey, Berlin, pp 79-108

Stechmann D-H, Schütte F (1978) Zur endophytischen Eiablage von Dasineura brassicae Winnertz, 1853 (Dipt., Cecidomyiidae). J Appl Entomol 85:412-424. https://doi.org/10.1111/j.1439-0418. 1978.tb04052.x
Sylvén E (1949) Skidgallmyggan, Dasyneura brassicae Winn. Statens Växtskyddanstalt Mededeling 54:1-120

Sylvén E (1970) Field movement of radioactively labelled adults of Dasyneura brassicae Winn. (Dipt., Cecidomyiidae). Insect Syst Evol 1:161-187. https://doi.org/10.1163/187631270X00014

Thiem E (1970) Die Bedeutung der Feldrandbehandlung für die Bekämpfung von Dasineura brassicae Winn (Dipt., Cecidomyiidae) und Ceuthorrhynchus assimilis Payk. (Col., Curculionidae) im blühenden Raps und der Einfluss dieser Insektizidmaßnahme auf das Vorkommen von Trichomalus perfectus Walker (Hym., Chalcidoidaea Pteromalidae) an den Larven des Kohlschotenrüßlers. Archiv Für Pflanzenschutz 6:83-98

Ulber B, Klukowski Z, Williams IH (2010) Impact of insecticides on parasitoids of oilseed rape pests. In: Williams IH (ed) Biocontrol-based integrated management of oilseed rape pests, vol 18 . Springer, Dordrecht, pp 337-355

Ulber B, Williams IH, Klukowski Z, Luik A, Nilsson C (2010) Parasitoids of oilseed rape pests in Europe: key species for conservation biocontrol. In: Williams IH (ed) Biocontrol-based integrated management of oilseed rape pests. Springer, Dordrecht, pp 45-76

Venables WN, Ripley BD (2007) Modern applied statistics with S. Statistics and computing, 4th edn. Springer, New York

Waede M (1960) Über den Gebrauch einer verbesserten Lichtfalle zur Ermittlung der Flugperioden von Gallmücken. Nachr Dtsch Pflanzenschutzd 12:45-47

Warner DJ, Allen-Williams LJ, Ferguson AW, Williams IH (2000) Pest-predator spatial relationships in winter rape: Implications for integrated crop management. Pest Manag Sci 56:977-982. https://doi.org/10.1002/1526-4998(200011)56:11\%3c977:AIDPS224\%3e3.0.CO;2-U

Williams IH (1990) Monitoring Dasineura brassicae by means of pheromone traps. IOBC/WPRS Bull 13:40-45

Williams IH (ed) (2010) Biocontrol-based integrated management of oilseed rape pests. Springer, Dordrecht

Williams IH (2010) The major insects pests of oilseed rape in Europe and their management: an overview. In: Williams IH (ed) Biocontrol-Based Integrated Management of Oilseed Rape Pests. Springer, Dordrecht, pp 1-43

Williams IH, Cook SM (2010) Crop location by oilseed rape pests and host location by their parasitoids. In: Williams IH (ed) Biocontrol-based integrated management of oilseed rape pests. Springer, Dordrecht, pp 215-244

Williams IH, Free JB (1979) Compensation of oilseed rape (Brassica napus L.) plants after damage to their buds and pods. J Agric Sci 92:53-59. https://doi.org/10.1017/S0021859600060494

Williams IH, Martin A (1986) Evidence for a female sex pheromone in the brassica pod midge Dasineura brassicae. Physiol Entomol 11:353-356. https://doi.org/10.1111/j.1365-3032.1986.tb00423.x

Williams IH, Martin AP, Kelm M (1987) The phenology of the emergence of brassica pod midge (Dasineura brassicae Winn.) and its infestation of winter oilseed rape (Brassica napus L.). J Agric Sci 108:579-589

Williams IH, Martin AP, Kelm M (1987) The phenology of the emergence of brassica pod midge (Dasineura brassicae Winn.) and its infestation of spring oilseed rape (Brassica napus L.). J Agric Sci 109:309-314

Williams IH, Ferguson AW, Kruus M, Veromann E, Warner DJ (2010) Ground beetles as predators of oilseed rape pests: incidence, spatio-temporal distributions and feeding. In: Williams IH (ed) Biocontrol-based integrated management of oilseed rape pests. Springer, Dordrecht, pp 115-149

Winfield AL (1992) Management of oilseed rape pests in Europe. Agric Zool Rev 5:51-95

Winnertz J (1853) Beitrag zu einer Monographie der Gallmücken. Linnaea Entomologica 8:154-322 
Zheng X, Koopmann B, Ulber B, von Tiedemann A (2020) A global survey on diseases and pests in oilseed rape-Current challenges and innovative strategies of control. Front Agron 2:590908. https://doi.org/10.3389/fagro.2020.590908
Publisher's Note Springer Nature remains neutral with regard to jurisdictional claims in published maps and institutional affiliations. 